\title{
Caloric Test as a Possible Prognostic Indicator in Sudden Deafness
}

\author{
Eun Jung Lim, Jung Soo Kim², Sung Jae $\mathrm{Heo}^{2}$, Jin Geol Lee ${ }^{1}$, \\ Ki Hwan Kwak ${ }^{1}$, Joo Hyeon Shin ${ }^{1}$, and SungHee Kim ${ }^{1}$ \\ ${ }^{I}$ Department of Otolaryngology-Head and Neck Surgery, Daegu Fatima Hospital, Daegu; and \\ ${ }^{2}$ Department of Otorhinolaryngology-Head and Neck Surgery, School of Medicine, Kyungpook National University, Daegu, Korea
}

\section{돌발성 난청에서 온도안진검사의 의의}

임은정 ${ }^{1} \cdot$ 김정수 $^{2} \cdot$ 허성재 $^{2} \cdot$ 이진걸 ${ }^{1} \cdot$ 곽기환 $^{1} \cdot$ 신주현 $^{1} \cdot$ 김성희 $^{1}$

대구파티마병원 이비인후과, ${ }^{1}$ 경북대학교 의학전문대학원 이비인후-두경부외과학교실 ${ }^{2}$

Received August 9, 2017

Revised October 12, 2017

Accepted October 31, 2017

Address for correspondence

SungHee Kim, MD, PhD

Department of Otolaryngology-

Head and Neck Surgery,

Daegu Fatima Hospital,

99 Ayang-ro, Dong-gu,

Daegu 41199, Korea

Tel $+82-53-940-7350$

Fax $+82-53-940-7352$

E-mail sungheekim@fatima.or.kr
Background and Objectives Dizziness has been known as a prognostic factor in sudden sensorineural hearing loss (SSHL), but it is difficult to describe and quantify its subjective symptoms. Also, dizziness itself cannot imply vestibular dysfunction in SSHL. Comprehensive evaluation of vestibular function may help us understand the extent of lesions in sudden deafness. The purpose of this study is to determine whether an impaired caloric response is associated with disease severity and hearing outcome.

Subjects and Method A retrospective chart review was conducted of 488 patients diagnosed as unilateral SSHL. The patients were divided into two, an abnormal caloric group (canal paresis $>20 \%$ ) and normal caloric group (canal paresis $\leq 20 \%$ ). Initial demographic and audiologic findings and final hearing outcomes were compared between the two groups.

Results The initial pure tone averages of SSHL patients of abnormal caloric group and normal caloric group were $75.4 \pm 28.4 \mathrm{~dB}$ HL and $68.2 \pm 25.4 \mathrm{~dB}$ HL $(p=0.004)$, respectively. Patients of abnormal caloric test group showed worse hearing outcome across all frequencies compared to those of the normal caloric group. Also, a significant correlation was noted between the magnitude of hearing recovery and canal paresis $(r=-0.223, p<0.001)$.

Conclusion SSHL patients of abnormal caloric test showed worse initial hearing level and poorer hearing outcome. Evaluation of vestibular function in SSHL patients is important because subjective symptoms alone cannot account for vestibular hypofunction patients, and the caloric test can help in the counseling of patients and prediction of hearing outcome in SSHL patients. Korean J Otorhinolaryngol-Head Neck Surg 2018;61(10):508-13

\section{서 론}

돌발성 난청은 이비인후과적 응급질환이기는 하나 병인을 정확히 찾기 어렵고 치료에 대해 경험적 치료가 이루어지고 있

This is an Open Access article distributed under the terms of the Creative Commons Attribution Non-Commercial License (https://creativecommons.org/licenses/by-nc/4.0) which permits unrestricted non-commercial use, distribution, and reproduction in any medium, provided the original work is properly cited.
어 돌발성 난청에서 포괄적인 내이 기능에 대한 평가가 병의 정 도와 병인을 이해하는데 도움이 될 것으로 생각된다. ${ }^{1,2)}$ 현재 돌발성 난청의 예후인자에 관한 많은 연구들이 발표되고 있 으며 초기 청력 소실의 정도, 청력도의 형태, 치료개시 시간, 나이, 어지러움의 동반 여부 등이 중요한 예후인자로 보고되 어진다. ${ }^{3)}$ 이 중 어지럼증은 대표적인 돌발성 난청의 예후인자 이나 주관적으로 환자가 느끼는 증상으로 이를 정성적, 정량 
적으로 평가하기 어려우며 어지럼증 유무가 객관적인 전정기 능검사 결과와 일치하지 않는 경우가 많아 어지럼 증상이 없 다 하여 전정기능계를 침범하지 않았다고 판단하기는 어렵 다. 일반적으로 돌발성 난청에서 전정기능이 저하된 경우 좀 더 광범위한 내이의 병변을 의미하는 것으로 고려되며 나쁜 예후가 예측된다는 연구들이 있으나 ${ }^{2,4)}$ 어지럼증이 없는 환 자들을 포함하여 전정기능검사 결과와 돌발성 난청의 예후 에 대해서는 연구가 많지 않다. ${ }^{1)}$

이에 저자들은 돌발성 난청 환자의 온도안진검사(caloric test)를 후향적으로 분석하여 온도안진검사의 이상여부, 특히 반규관 마비가 돌발성 난청의 예후에 관계가 있는지 확인하 고자 하였다.

\section{대상 및 방법}

본 연구는 2010년 9월부터 2017년 3월까지 본원 이비인후 과에서 돌발성 난청으로 진단되어 입원치료를 시행 받은 총 982명(982귀)을 대상으로 후향적 연구를 시행하였다. 모든 환자들은 3 일 이내에 연속된 3 개의 주파수에서 $30 \mathrm{~dB}$ 이상 의 갑작스러운 청력 저하를 보이는 돌발성 난청의 기준을 만 족하였다. 이 중 발병 후 2주가 지나 병원을 방문하였거나 치 료 후 경과 관찰이 1 개월 이상 되지 않은 환자는 제외하였다. 또한 메니에르씨병, 중추성 현훈, 재발성 또는 양측성 돌발성 난청, 소뇌교각종양 등의 병력이 있거나 중이염 또는 병변귀 가 유일청인 경우, 온도안진검사상 양측 전정기능 소실 소견 을 보이거나 반대측 귀의 반규관 마비 소견을 보이는 경우를 제외하였다(Table 1).

환자들은 7일간 입원치료를 하였으며 Dexamethasone (Dexamethasone sodium phosphate $5 \mathrm{mg} / \mathrm{mL}$; Yuhan Corp., Seoul, Korea)을 하루 2회 정맥주사하였으며 이후 퇴 원하여 7일에 걸쳐 경구 스테로이드인 Solondo(Prednisolone

Table 1. Reason for excluded ears from total 982 ears

\begin{tabular}{lr}
\hline \multicolumn{1}{c}{ Reason for exclusion } & No. \\
\hline History of otitis media & 33 \\
Pre-existing hearing loss, only ear, better ear & 76 \\
Meniere's disease & 47 \\
Bilateral vestibulopathy (caloric sum <12 degree/sec) & 46 \\
Contralateral vestibulopathy (canal paresis > 20\%) & 58 \\
Short follow-up period (less than 1 month) & 80 \\
Late hospital visit (more than 14 days after disease onset) & 55 \\
Recurrent of bilateral sudden deafness & 37 \\
Caloric test was not tested & 52 \\
Central lesion (acoustic neuroma or etc.) & 10 \\
\hline Total & 494 \\
\hline
\end{tabular}

5 mg; Yuhan Corp.)를 $30 \mathrm{mg} / \mathrm{day}$ 4일, $15 \mathrm{mg} / \mathrm{day}$ 3일로 감량 치료하였다. 입원기간 동안 통증의학과에서 성상신경차 단술을 하루 1 회씩 시행하였으며 Carbogen $\left(5 \% \mathrm{CO}_{2}\right.$ 와 $95 \%$ $\mathrm{O}_{2}$ 로 구성된 혼합가스)을 입원 기간 동안 1 일 8회, 1 시간 간 격으로 30분씩 흡입하도록 하였다. ${ }^{5)}$ 고실내 Dexamethasone (Dexamethasone sodium phosphate $5 \mathrm{mg} / \mathrm{mL}$ ) 주입술을 1주 일에 2회씩 총 4회 시행하였으며 해당된 488명의 환자는 모 두 온도안진검사를 시행 받았다.

청력 검사는 치료 전 초기 순음청력도와 치료 후 청력이 어 느 정도 안정되었다고 판단되는 치료 후 최소 1 개월이 경과 한 시점의 순음청력도를 기준으로 청력 역치를 평가하였다. 평균 청력은 $0.5,1,2,3 \mathrm{kHz}$ 를 4분법으로 평균하였다. 치료 전후 청력 회복 정도는 초기 청력의 평균값에서 치료 후 청력 의 평균값을 뺀 값으로 정하였다. 또한 Siegel이 제시한 판정 표를 기준으로 최종 $25 \mathrm{~dB}$ 역치 이내로 청력 호전이 있는 경 우를 완전회복(grade I), $15 \mathrm{~dB}$ 이상 청력 호전이 있고 최종 청력이 25 45 dB 범위의 청력 역치인 경우를 부분회복 (grade II), $15 \mathrm{~dB}$ 이상 청력 호전이 있고 최종 $45 \mathrm{~dB}$ 초과의 청력 역치인 경우를 경도회복(grade III), $15 \mathrm{~dB}$ 미만으로 청 력 호전이 있거나 최종 $75 \mathrm{~dB}$ 이상 청력 역치인 경우를 불변 (grade IV)으로 구분하였으며 grade I, II, III을 청력 회복이 있는 경우로 판정하였으며 grade IV를 청력 회복이 없는 경우 로 분석하였다.

온도안진검사는 어두운 방에서 눈을 뜬 상태로 검사가 진 행되었으며 비디오 안구운동검사기를 이용하여 안구의 운동 을 측정하였다. 냉온 교대온도 자극은 air caloric stimulator (Air Fix; Interacoustics, Middelfart, Denmark)를 통해 24도 와 50도의 공기 $8 \mathrm{~L}$ 를 60 초간 외이도에 지속적으로 관류하도 록 하였다. 병변측의 편측 마비가 $20 \%$ 를 초과하는 경우를 반규관 마비(canal paresis)라 정의하였으며 온 자극과 냉 자 극으로 발생한 안진의 느린 반응의 최고 속도의 합이 양쪽에 서 모두 12 degree/sec 이하인 환자는 양측 전정기능 소실 소 견으로 배제되었으며 반대측 반규관 마비가 있는 환자도 배 제되었다. 온도안진검사상 반규관 마비 여부가 청력 회복에 미 치는 영향을 알아보았다. 아울러 내원 당시 어지럼증의 유무 에 의한 영향도 함께 분석하였다.

통계분석은 independent t-test, chi-square test, score test for trend를 사용하여 반규관 마비가 있는 군과 없는 군 간에 비교를 하였다. 반규관 마비정도(magnitude)와 초기 청력 역 치와 청력 회복 정도의 관련성을 알아보기 위해 correlation test를 시행하였다. 반규관 마비 정도, 나이, 초기 청력 정도, 치 료개시 시간의 변수들을 포함하여 다중회귀분석(multivariate regression analysis)을 사용하여 분석하였다. 
Table 2. Comparison of initial demographic findings between patients with normal and abnormal caloric response

\begin{tabular}{|c|c|c|c|}
\hline & \multicolumn{2}{|c|}{ Caloric test } & \multirow{2}{*}{$p$ value } \\
\hline & $C P \leq 20 \%(n=304, \%)$ & $C P>20 \% \quad(n=184, \%)$ & \\
\hline \multicolumn{4}{|l|}{ Sex } \\
\hline Male & $141(46.4)$ & $88(47.8)$ & 0.757 \\
\hline Female & $163(53.6)$ & $96(52.2)$ & \\
\hline Age (years) & $49.8 \pm 15.8$ & $51.8 \pm 13.8$ & 0.149 \\
\hline \multicolumn{4}{|l|}{ Initial PTA (dB HL) } \\
\hline Mild $(\leq 40)$ & $50(16.4)$ & $21(11.4)$ & \\
\hline Moderate $(\leq 55)$ & $59(19.4)$ & $31(16.8)$ & \\
\hline Moderate-severe $(\leq 70)$ & $65(21.4)$ & $36(19.6)$ & $0.007^{*}$ \\
\hline Severe $(\leq 90)$ & $62(20.4)$ & $30(16.3)$ & \\
\hline Profound (>90) & $68(22.4)$ & $66(35.9)$ & \\
\hline Interval before first visit (days) & $3.7 \pm 2.8$ & $4.5 \pm 3.4$ & $0.007^{*}$ \\
\hline \multicolumn{4}{|l|}{ Side } \\
\hline Right & $142(46.7)$ & $73(39.7)$ & 0.129 \\
\hline Left & $163(53.3)$ & $112(60.3)$ & \\
\hline \multicolumn{4}{|l|}{ Dizziness } \\
\hline$(-)$ & $202(66.4)$ & $136(73.9)$ & 0.083 \\
\hline$(+)$ & $102(33.6)$ & $48(26.1)$ & \\
\hline
\end{tabular}

PTA of $0.5,1,2$, and $3 \mathrm{kHz}$. *statistically significant $(p<0.05)$. CP: canal paresis, PTA: pure-tone average, HL: hearing level

Table 3. Comparison of pure-tone average of initial and posttreatment and hearing improvement after treatment between patients with normal and abnormal caloric test

\begin{tabular}{lccr}
\hline & \multicolumn{2}{c}{ Caloric test } & p value \\
\cline { 2 - 3 } & $\mathrm{CP} \leq 20 \%(\mathrm{n}=304)$ & $\mathrm{CP}>20 \%(\mathrm{n}=184)$ & \\
\hline Initial & $68.2 \pm 25.4$ & $75.4 \pm 28.4$ & $0.004^{*}$ \\
Post-treatment & $36.6 \pm 24.2$ & $51.1 \pm 31.8$ & $<0.001^{*}$ \\
Improvement & $31.9 \pm 23.3$ & $23.9 \pm 22.1$ & $<0.001^{*}$ \\
\hline
\end{tabular}

*statistically significant $(p<0.05)$. CP: canal paresis

또한 어지러움 증상의 유무에 따라 군 간에 비교를 같은 통계분석을 이용하여 비교하였다.

통계적인 처리는 SPSS 12.0(SPSS software, SPSS Inc., Chicago, IL, USA)을 이용하여 분석하였으며, 통계 결과는 $p$ value가 0.05 미만인 결과의 경우 유의한 차이가 있는 것으 로 판단하였다. 본 후향적 연구는 헬싱키 선언에 따라 기관윤 리심의위원회(Institutional Review Board)의 승인(IRB No. DFE17ORIO025)을 받았다.

\section{결 과}

최종 해당된 환자는 488명으로 이들 중 남자는 229명 (46.9\%), 여자는 259명(53.1\%)이었으며 평균 나이는 50.7세로 7세부터 85세까지 다양하게 분포하였다.

전체 환자 중 온도안진검사상 반규관 마비가 있는 환자는 184 명(37.7\%), 온도안진검사가 정상인 환자는 304명(62.2\%) 이었다. 환자의 성별, 나이, 병변측의 방향 및 어지럼증의 유
무는 두 군 간 차이를 보이지 않았다. 초기 청력을 비교하였을 때 반규관 마비군은 경도 난청이 $11.4 \%$, 중등도 난청이 $16.8 \%$, 중등고도 난청이 $19.6 \%$, 고도 난청이 $16.3 \%$, 농이 $35.9 \%$ 이며, 반규관 마비가 없는 정상군은 경도 난청이 $16.4 \%$, 중등도 난 청이 $19.4 \%$, 중등고도 난청이 $21.4 \%$, 고도 난청이 $20.4 \%$, 농 이 22.4\%로 양 군 간에 통계적으로 유의하게 초기 청력 정도 에 차이가 있었다 $(p=0.007)$. 또한 치료개시 시간이 반규관 마 비가 없는 정상군은 $3.7 \pm 2.8$ 일로 반규관 마비군의 $4.5 \pm 3.4$ 일 에 비해 유의하게 짧았다 $(p=0.007)$ (Table 2).

반규관 마비군과 반규관 마비가 없는 정상군간 청력의 회 복 정도를 비교해 보았을 때 통계적으로 유의하게 두 군간 차 이를 보였으며 $(p<0.001$ )(Table 3) Siegel의 판정표를 기준으 로 평가하였을 때에도 두 군간 통계적으로 유의한 차이를 보 였다 $(p<0.001$ )(Fig. 1). 반규관 마비의 정도(magnitude)와 청 력간의 관계를 분석하였을 때, 반규관 마비의 정도와 초기 청 력은 양의 상관관계(Pearson's; $\mathrm{r}=0.141, p=0.002)$ 를 보였으 며 반규관 마비의 정도와 청력 회복의 정도는 음의 상관관계 (Pearson's; $\mathrm{r}=-0.223, p<0.001$ )를 보여 반규관 마비의 정도 가 심할수록 초기 청력 역치가 높고 회복 정도가 낮음을 확인 할 수 있었다(Fig. 2).

청력 회복 정도에 미치는 영향을 분석하기 위해 기존에 알 려진 예후인자들과 반규관 마비 정도를 함께 다중 선형회귀 분석을 시행한 결과 초기 청력 정도, 반규관 마비 정도, 나이, 치료개시 시간이 모두 유의하게 청력 회복 정도에 영향을 미 치는 것으로 파악되었고, 이 모델에 의한 설명력은 $R^{2}=0.272$ 
였다(Table 4).

이에 반해 예상과 달리 주관적인 어지럼증의 여부는 통계 적으로 유의하게 청력 회복과 상관관계를 보이지 않았다. 주 관적인 어지러움을 호소하는 환자(총 150명) 중 반규관 마비 를 보이는 환자는 48명(32\%)였으며 반규관 마비가 없는 정 상군은 102명(68\%), 어지러움이 없는 환자(총 338명) 중 반규 관 마비를 보이는 환자는 136 명(40.2\%)이었으며 반규관 마비 가 없는 정상군은 202 명(59.7\%)이었다. 어지럼증이 있는 환자 군(150명)과 없는 환자군(338명)에서 초기 청력 정도와 청력 호전 정도를 비교해 본 결과 통계적으로 유의한 차이는 없었 으며(Table 5), Siegel의 판정표를 기준으로 회복 정도를 분

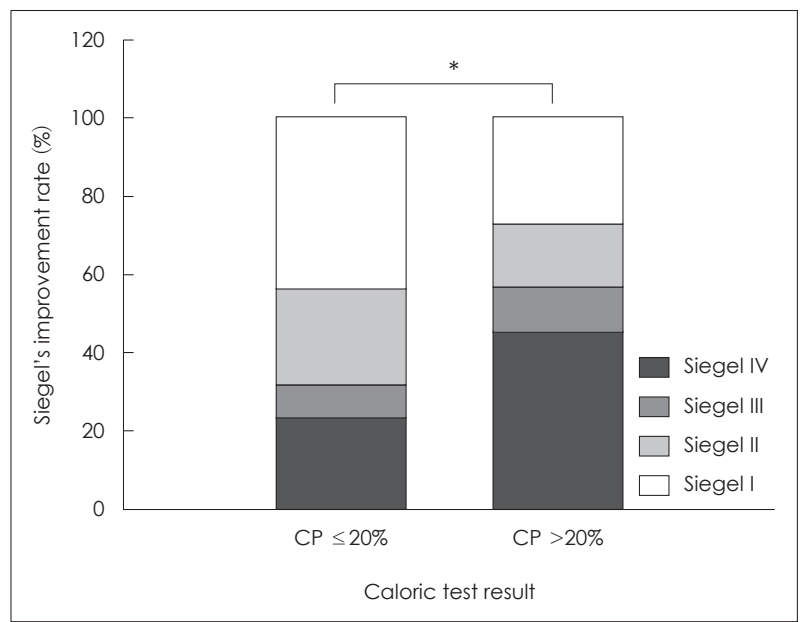

Fig. 1. Comparison of hearing outcome in $\mathrm{CP}$ and normal caloric group according to Siegel's criteria. In CP group (CP $>20 \%$ ), Siegel grade I, II, III, and IV were $27 \%, 16 \%, 12 \%$, and $45 \%$. In normal caloric group, Siegel grade I, II, III, and IV were $44 \%, 25 \%, 8 \%$, and $23 \%$, respectively. Considering Siegel I, II, and III as hearing improvement, hearing outcome was significantly worse in CP group $(p<0.001)$. * ${ }^{*}$ tatistical significance $(p<0.001)$. CP: canal paresis.
석을 하였을 때 주관적인 어지럼증은 청력 개선 정도에 차이 가 없었다 $(p=0.612)$ (Fig. 3).

\section{고 찰}

돌발성 난청은 3일 이내의 시간 동안 급작스럽게 청력 소실 을 일으키는 응급질환으로 아직 병인에 대한 정확한 확인이 어렵고 경험적인 치료들이 시행되고 있는 실정이다. 돌발성 난 청의 예후와 관계되는 요소로는 초기의 청력 정도, 치료개시 시간, 나이, 어지러움의 유무 등이 일반적으로 통용되는 사항 이나 ${ }^{6,7)}$ 이에 대해서도 이견을 제시하는 보고들이 많다..$^{8-11)}$ 본 연구에서는 예상과 달리 주관적 어지러움의 여부는 청력

Table 4. Multivariate regression analysis for hearing improvement $^{\dagger}$

\begin{tabular}{lcccc}
\hline \multicolumn{1}{c}{ Variable } & $\mathrm{B}$ & $\mathrm{SE}$ & $\beta$ & $\mathrm{p}$ value \\
\hline Initial PTA & 0.376 & 0.036 & 0.433 & $<0.001^{*}$ \\
CP & -0.209 & 0.034 & -0.244 & $<0.001^{*}$ \\
Age & -0.287 & 0.062 & -0.187 & $<0.001^{*}$ \\
Interval $^{\ddagger}$ & -1.061 & 0.304 & -0.140 & $0.001^{*}$ \\
\hline
\end{tabular}

*statistically significant $(p<0.05)$, thearing improvement calculated by initial PTA minus post-treatment PTA, tinterval before first visit. SE: standard error, CP: canal paresis, PTA: pure-tone average

Table 5. Comparison of pure-tone average of initial, post-treatment and hearing improvement between patients with and without dizziness

\begin{tabular}{lccc}
\hline & $\begin{array}{c}\text { Non-dizziness } \\
(\mathrm{n}=338)\end{array}$ & $\begin{array}{c}\text { Dizziness } \\
(\mathrm{n}=150)\end{array}$ & p value \\
\hline Initial & $71.1 \pm 70.3$ & $70.3 \pm 26.4$ & 0.761 \\
Post-treatment & $42.1 \pm 29.0$ & $42.3 \pm 28.1$ & 0.963 \\
Improvement & $29.1 \pm 23.2$ & $28.2 \pm 23.3$ & 0.928 \\
\hline
\end{tabular}

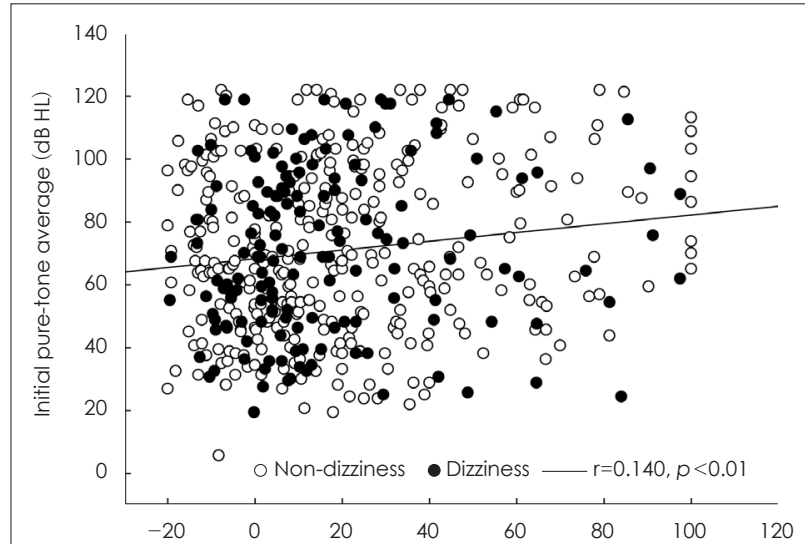

A

Fig. 2. Correlation of the magnitude of $\mathrm{CP}$ and $\mathrm{HL}$. The magnitude of $\mathrm{CP}$ and initial $\mathrm{HL}$ was positively correlated (pearson's $r=0.141$, $p=0.002)$. As the amount of CP increases, initial hearing threshold was higher $(A)$. The magnitude of CP and hearing improvement was negatively correlated (pearson's $r=-0.223, p<0.001)(B)$. As the amount of $C P$ increases, the magnitude of hearing improvement was lowered. CP: canal paresis, HL: hearing level.

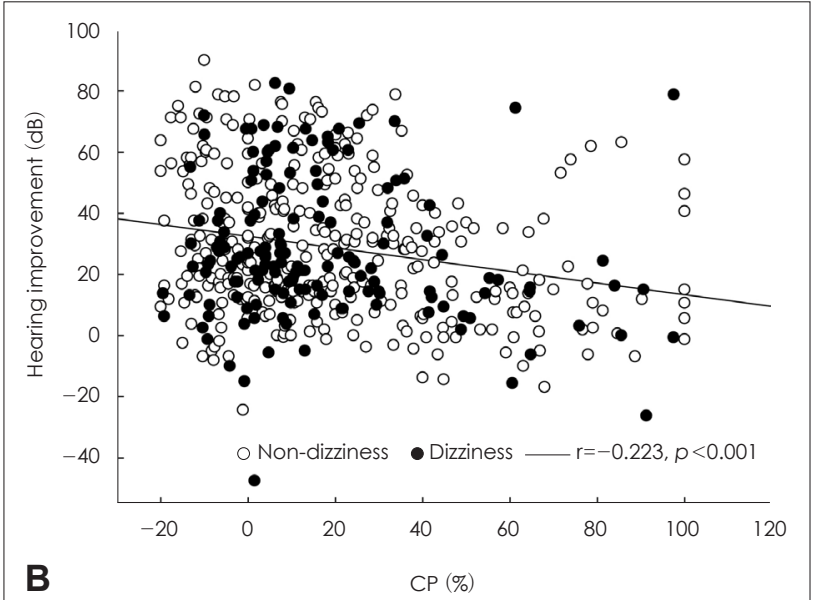

B 


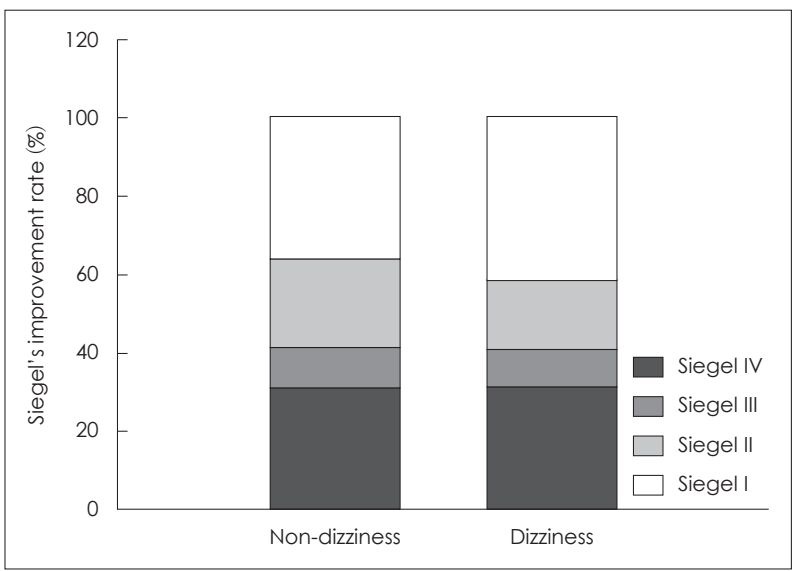

Fig. 3. Comparison of hearing outcome in dizziness and non-dizziness group according to Siegel's criteria. The hearing outcome was not different among two groups ( $p=0.612)$.

의 회복 정도에 영향을 미치지 않는 것으로 분석되었다. 기존 의 대다수의 연구들에서는 어지러움 동반 시 나쁜 예후를 보고하고 있으나 구조적으로 와우의 기저부와 전정기관이 인접하므로 기저부의 손상을 의미하는 고음역의 난청과 고 도 난청에서 더 많은 어지러움을 호소하고 있으며 이러한 청 력형의 경우 일반적으로 회복률이 저조한 경향을 보이므로 이로 인한 영향을 고려해야 한다고 보고하였다. ${ }^{6,8,12,13)}$ 또한 Berg와 Pallasch ${ }^{14}$ 도 불량한 초기 청력도를 고려하였을 경우 어지러움이 최종적인 청력 회복 정도에는 영향을 미치지 못 할 것이라고 보고하였다. 그 외에도 본 연구 결과와 마찬가지 로 어지러움 증상 자체가 청력 회복의 정도와 관계가 없었다 는 연구들도 발표되었다.911,12) 기존의 연구에서도 어지러움의 정도와 전정기관의 마비 정도는 관계가 없다는 보고가 있었 으며 ${ }^{15-17)}$ Inagaki 등 ${ }^{18)}$ 은 어지러움이 있는 환자와 없는 환자 간에 전정 유모세포의 밀도 및 조직학적 검사에 차이가 없음 을 보고하였다.

Wilson 등 ${ }^{12)}$ 과 Liu 등 ${ }^{15)}$ 은 주관적인 어지럼증보다는 객관 적인 전정기능 검사 결과가 돌발성 난청의 좀 더 예민한 예후 의 척도가 될 수 있음을 보고하였다. 일반적으로 와우의 손 상 정도가 심할수록 내이의 병변이 광범위할 것으로 생각이 되며 어지러움 여부에 관계없이 전정기관도 침범이 될 것이 라 추정된다. ${ }^{11,15,18)}$ 이러한 전정기관 마비군들은 상대적으로 내이의 병변이 심하여 기존 청력 저하 정도가 심하며 청력의 회복도가 낮은 것으로 보고된다. ${ }^{1,4)}$

본 연구 결과에서도 어지럼증이 있는 환자는 총 150 명으 로 전체 돌발성 난청 환자 중 $30.7 \%$ 로 기존의 보고 결과와 비교적 일치하는 소견을 보였다. ${ }^{67)}$ 하지만 실제 어지러움을 호소하지 않는 상당수의 환자에서 온도안진검사상 반규관 마비 소견을 보였으며 반규관 마비 환자의 비율로만 보았을
때 주관적인 어지럼증과 온도안진검사 결과가 일치하지 않는 소견을 보였다.

어지러움이 있는 환자에서도 전정기능검사가 정상인 환자 가 많았으며,8,12) 어지러움을 호소하지 않는 환자를 대상으로 시행한 기존의 연구들에서 확인해보면 평균적으로 약 $40 \%$ 정도의 돌발성 난청 환자가 전정기능 저하 소견을 보이는 것 으로 보고되어 증상은 없지만 잠재적으로 전정기능의 저하 를 보이는 환자들이 있음을 알 수 있다. ${ }^{15,19)}$

돌발성 난청 환자에 있어 다양한 전정기능검사들과 예후 의 상관관계에 대한 보고가 있었으나 다수의 연구가 돌발성 난청 환자 중 어지러움 증상이 있는 환자만을 대상으로 전정 기능검사를 시행하여 전체 돌발성 난청 환자의 예후에 대한 정보를 제공하기는 어려웠다. ${ }^{4,15,17,20)}$ 어지러움이 없는 돌발성 난청 환자를 포함한 연구들에서는 전정기능검사 결과가 예 후를 예측하는 데 도움이 됨을 보고하였지만 좀 더 예민하게 전정기능의 저하 및 예후를 예측하는 검사의 종류에 대해서 는 이견을 제시하였다. ${ }^{1,11,19,20)}$

Jung 등 ${ }^{19}$ 의 연구에 따르면 전정유발근전위검사(vestibularevoked myogenic potential, VEMP)와 온도안진검사를 시 행한 연구에서 VEMP 검사 결과가 온도안진검사보다 민감하 게 청력 회복 정도를 예측하는 측도가 됨을 보고하였으며 어 지러움 증상이 없는 잠재적 전정기능 장애군에서도 청력 회 복 정도가 낮음을 보고하였다. VEMP 결과가 온도안진검사 보다 돌발성 난청에서 전정기관의 손상 정도를 잘 반영한다 는 보고들은 해부학적으로 구형낭이 와우와 가까운 위치에 존재하기 때문에 동시에 손상 가능성이 크고 구형낭과 와우 안에 존재하는 유모세포의 구조의 유사성 및 공통된 혈액 공급을 받는다는 사실을 기반으로 VEMP 검사가 예후를 가 늠해 볼 수 있는 좋은 진단 수단이 됨을 설명하였다. ${ }^{19,21)}$

하지만 Shih 등과 과 Narozny 등ㅎㅇㅇㅣ 돌발성 난청의 예후인 자로서 온도안진검사의 유용성을 보고하였으며 특히 Shih 등의 연구에서는 온도안진검사상 반규관 마비가 청력 회복 정도에 통계적으로 유의하게 상관관계가 있으며 특히 반규 관 마비가 $40 \%$ 이상 되는 환자에서 통계적으로 유의하게 병 의 호전이 없음을 확인하여 보고하였다. 반규관 마비군들은 상대적으로 내이의 병변이 심하여 초기 청력 저하 정도가 심 한 것으로 보고되며,4) 본 연구에서도 같은 결과를 보였다 (Table 3). 어지러움 증상이 없는 잠재적인 전정기능 장애군 의 경우에도 마찬가지 원리로 청력 회복에 있어 나쁜 예후를 보임이 확인되어 이들에 대한 관심이 요구된다.

온도안진검사는 돌발성 난청의 예후에 있어서 대다수의 연구 에서 일관되게 병의 예후와 관계있는 것으로 보고된다.,8-10,12,22) 본 연구결과에서도 주관적인 어지러움 증상 여부보다는 온 
도안진검사 결과가 좀 더 병의 예후를 판정하는데 도움이 되 는 것으로 확인되었으며 반규관 마비 정도와 청력 호전 정도 가 통계적으로 유의하게 음의 상관관계를 보임을 확인할 수 있었다(Fig. 2B). 다만 초기 청력 저하 정도가 반규관 마비군 의 경우 정상군에 비해 더 심하여 이러한 인자를 보정한 추가 적인 연구가 필요할 것으로 생각된다.

상기의 검사는 어지러움을 후향적 진료기록으로 확인하여 이로 인한 한계가 있을 것으로 생각되며 대상 환자들이 2주 일 이내에 치료를 시작하여 입원기간동안 온도안진검사를 받았는데 일시적인 전정기능 장애의 경우 이미 검사 시 병변 이 정상화되었을 가능성을 고려해야 할 것이다. ${ }^{17)}$ 또한 온도 안진검사의 경우 반고리관의 기능만을 반영하여 총체적인 전 정기관의 기능을 반영하기는 어려우며 온도안진검사 결과의 척도 중 반규관 마비(canal paresis)만을 대상으로 하여 방향 우위성(directional preponderance) 등에 대한 추가적인 연구 가 있어야 할 것이다.

그러나 상기 연구는 동일한 치료를 시행 받은 비교적 많은 수의 환자를 대상으로 하였으며 어지러움 증상이 없는 환자 를 포함하여 잠재적인 말초 전정기능 저하를 가진 환자군을 확인하였으며 전체 환자들의 병의 경과를 온도안진검사에 대 비해 비교하였다. 특히 정성적, 정량적으로 평가하기 어려운 어지러움 증상의 여부보다 객관적인 온도안진검사 결과가 돌 발성 난청 환자의 예후를 가늠하는 지표가 될 수 있음을 뒷 받침하는 연구라 생각된다.

\section{REFERENCES}

1) Shih CP, Chou YC, Chen HC, Lee JC, Chu YH, Wang CH. Analysis of caloric testresponses in sudden hearing loss. Ear Nose Throat $\mathrm{J}$ 2017;96(2):59-64

2) Wang CT, Huang TW, Kuo SW, Cheng PW. Correlation between audiovestibular function tests and hearing outcomes in severe to profound sudden sensorineural hearing loss. Ear Hear 2009;30(1): 110-4.

3) Laird N, Wilson WR. Predicting recovery from idiopathic sudden hearing loss. Am J Otolaryngol 1983;4(3):161-4.

4) Iwasaki S, Takai Y, Ozeki H, Ito K, Karino S, Murofushi T. Extent of lesions in idiopathic sudden hearing loss with vertigo: study using click and galvanic vestibular evoked myogenic potentials. Arch Otolaryngol Head Neck Surg 2005;131(10):857-62.

5) Fisch U. Management of sudden deafness. Otolaryngol Head Neck Surg 1983;91(1):3-8.
6) Shaia FT, Sheehy JL. Sudden sensori-neural hearing impairment: a report of 1220 cases. Laryngoscope 1976;86(3):389-98.

7) Nakashima T, Yanagita N. Outcome of sudden deafness with and without vertigo. Laryngoscope 1993;103(10):1145-9.

8) Mattox DE, Simmons FB. Natural history of sudden sensorineural hearing loss. Ann Otol Rhinol Laryngol 1977;86(4 Pt 1):463-80.

9) Narozny W, Kuczkowski J, Kot J, Stankiewicz C, Sicko Z, Mikaszewski B. Prognostic factors in sudden sensorineural hearing loss: our experience and a review of the literature. Ann Otol Rhinol Laryngol 2006;115(7):553-8.

10) Weiss D, Böcker AJ, Koopmann M, Savvas E, Borowski M, Rudack C. Predictors of hearing recovery in patients with severe sudden sensorineural hearing loss. J Otolaryngol Head Neck Surg 2017; 46(1):27.

11) Korres S, Stamatiou GA, Gkoritsa E, Riga M, Xenelis J. Prognosis of patients with idiopathic sudden hearing loss: role of vestibular assessment. J Laryngol Otol 2011;125(3):251-7.

12) Wilson WR, Laird N, Kavesh DA. Electronystagmographic findings in idiopathic sudden hearing loss. Am J Otolaryngol 1982;3(4):279-85.

13) Ahn JH, Yoon TH, Chung JW. Analysis of prognosis in patients with sudden sensorineural hearing loss and dizziness. Korean J Otolaryngol-Head Neck Surg 2001;44(10):1032-7.

14) Berg M, Pallasch H. Sudden deafness and vertigo in children and juveniles. Adv Otorhinolaryngol 1981;27:70-82.

15) Liu J, Zhou RH, Liu B, Leng YM, Liu JJ, Liu DD, et al. Assessment of balance and vestibular functions in patients with idiopathic sudden sensorineural hearing loss. J Huazhong Univ Sci Technolog Med Sci 2017;37(2):264-70.

16) Khetarpal U. Investigations into the cause of vertigo in sudden sensorineural hearing loss. Otolaryngol Head Neck Surg 1991;105(3): 360-71.

17) Park HM, Jung SW, Rhee CK. Vestibular diagnosis as prognostic indicator in sudden hearing loss with vertigo. Acta Otolaryngol Suppl 2001;545:80-3.

18) Inagaki T, Cureoglu S, Morita N, Terao K, Sato T, Suzuki M, et al. Vestibular system changes in sudden deafness with and without vertigo: a human temporal bone study. Otol Neurotol 2012;33(7): $1151-5$.

19) Jung SG, Park JW, Han SY, Park SH, Nam SI. The role of vestibular function tests in patients with sudden sensorineural hearing loss who have subclinical vestibular dysfunction. Korean J OtorhinolaryngolHead Neck Surg 2013;56(11):700-5.

20) Niu X, Zhang Y, Zhang Q, Xu X, Han P, Cheng Y, et al. The relationship between hearing loss and vestibular dysfunction in patients with sudden sensorineural hearing loss. Acta Otolaryngol 2016;136(3): 225-31.

21) Fujimoto C, Egami N, Kinoshita M, Sugasawa K, Yamasoba T, Iwasaki $\mathrm{S}$. Involvement of vestibular organs in idiopathic sudden hearing loss with vertigo: an analysis using oVEMP and cVEMP testing. Clin Neurophysiol 2015;126(5):1033-8.

22) Saeki N, Kitahara M. Assessment of prognosis in sudden deafness. Acta Otolaryngol Suppl 1994;510:56-61. 